\title{
AUGUSTUS, THE LUPERCALIA AND THE ROMAN IDENTITY
}

\begin{abstract}
Summary: It is widely agreed that Augustus dealt with the festival Lupercalia. However, the evidence about his intervention is scanty and discussable; in addition, both the reconstruction of the celebration and an outline of its historical development are almost impossible tasks. Nevertheless, ancient authors agree on placing the origins of the Lupercalia in the furthest antiquity, at the beginning of the town or at the beginning of mankind. Coherently, the descriptions which they provide suggest that the festival aimed at a temporary and ritually controlled regress to the primeval savagery. Therefore, the involvement of Augustus in the (re-)organization of the Lupercalia results to be consistent with his programmatic connection to Romulus, the founder. In fact, the representations of the pre-civic world at the festival and in the Augustan poetry (especially by Virgil) are consonant. It is worth noting that Lupercalia were celebrated for centuries after Augustus. It is possible to infer that the regress into the wild primeval world was essential to Roman identity, just like the stories about the founder. Since a festival Louperkalion was held in Constantinople, it can be supposed that Lupercalia were one of the identitary symbols that the second Rome chose as heritage from the first one.
\end{abstract}

Key words: Luperci, festival, symbol, identity, Romulus, pre-civic world, Virgilian poetry, Augustus

It is widely agreed that Augustus dealt with the festival Lupercalia. In fact, Suetonius includes the Lupercalia in a list of decayed traditional religious institutions and rituals which Augustus restored (Suet. Aug. 31. 4):

Nonnulla etiam ex antiquis caerimoniis paulatim abolita restituit, ut Salutis augurium, Diale flamonium, sacrum Lupercale, ludos Saeculares et Compitalicios. Lupercalibus vetuit currere inberbes (...)

He also revived some of the ancient rites which had gradually fallen into disuse, such as the augury of Safety, the office of Flamen Dialis, the ceremonies of the Lupercalia, the Secular Games and the festival of the Compitalia. At the Lupercalia he forbade beardless youths to join in the running (...) (Trans. J. C. Rolfe ${ }^{1}$ )

\footnotetext{
${ }^{1}$ See Suetonius. With an English translation by C. J. RoLFE. Vol. I. London - Cambridge, Mass. 1912.
} 
Suetonius states that Augustus forbade beardless boys to run during the festival. Scholars generally have inferred that he made the celebration more decent, therefore, on the basis of iconographical evidence, they have credited Augustus with having dressed the naked luperci (as Virgil and Ovid call them). ${ }^{2}$ In the oldest supposed representation of luper$c i$ (a fragmentary clay slab from Palatine), ${ }^{3}$ they are naked, but the luperci depicted in a statue from Fondi (beginning I AD) ${ }^{4}$ and in two funerary reliefs (II AD) ${ }^{5}$ are wearing a kind of quite long loincloth, very close to the one that was worn by the victimarii.

Coherently to such an interpretation of Augustan restoration of the Lupercalia as a moral reform of the festival, it has been suggested that the prince introduced a nuance of moral punishment in the hits of the luperci to women. ${ }^{6}$ In fact, according to Ovid (who reports the foundation myth), brides who had not become pregnant yet, offered their shoulders to be beaten by the luperci (Ov. Fast. 2. 425-452). Plutarch states that women submitted their hands to luperci just like schoolgirls (Caes. 61). After all, it is well known that Augustus imposed a tax to not married people and awarded the most numerous families. ${ }^{7}$ In addiction, a real fustigation is depicted in a mosaic from Thysdrus and in the sarcophagus of Aelia Afanacia (III AD) ${ }^{8}$. Finally, Pope Gelasius I in his letter against the proposal of reintroducing Lupercalia (496 AD) hints at this kind of rite stating that in the past the matronae themselves (and not trivial women) were stripped to be fustigated (c. Andr. 16).

To sum up, on the basis of Suetonius'passage and of a passage of Cicero's Pro Caelio (11.26) in which he lampoons the savage bad ways of the luperci and recalls that their group "dates from before the dawn of civilization and law", 9 it is quite accepted the theory that Augustus tamed luperci's bad ways and "made them a respectable fellowship, acceptable to bourgeois standards of behaviour". 10

Such a theory fits in very well with evidence that points to crediting Augustus with the transformation of the luperci into an equestrian priesthood: inscriptions dating from the I AD to the III AD record only equestrian luperci; ${ }^{11}$ Valerius Maximus (II 2.9) states that the Lupercalia and the trasvectio equitum were the two occasions in

${ }^{2}$ See Verg. Aen. 8. 663 and Ov. Fast. 2. 268.

${ }^{3}$ See TORTORella, S.: Lastra Campana di rivestimento. In CARAndini, A. - CAPPElli, R. (eds.): Roma. Romolo, Remo e la fondazione della città. Milano 2000, 251.

${ }^{4}$ See TORTORELla (n. 3) 248.

${ }^{5}$ See TORTORELla (n. 3) 249-250.

${ }^{6}$ See Holleman, A.W. J.: Ovid and the Lupercalia. Historia 22 (1973) 260-268; Holleman, A.W. J.: Pope Gelasius I and the Lupercalia. Amsterdam 1974, $27-28$.

${ }^{7}$ See Dio Cass. LIV 16. 1; Suet. Aug. 34.

${ }^{8}$ See respctively TORTORELla (n. 3) 252 and 253. To this documents should be added a relief bronze mirror probably depicting Venus fustigated by a god (Faunus or Lupercus) inside the Lupercal. See TORTORELLA (n. 3) 243-244.

${ }^{9}$ Cicero aims at ridiculing Caelius's accusers who charged him with being a lupercus and were luperci themselves. However, it will be shown below (p. 227) that Cicero is playing on the actual symbolism of luperci.

${ }^{10}$ See North, J. A. - MCLYNn, N.: Postscript to the Lupercalia: from Caesar to Andromachus. JRS 98 (2008) 177.

${ }^{11}$ For a collection of the inscriptions, see SCHEID, J. - GRANINO CECERE, M. G.: Les sacerdoces publics équestres. In Demougim, S. - DeVIJVER, H. - RAEPSAET-Charlier, M.-Th. (eds.): L'ordre équestre. Histoire d'une aristocratie ( $\left(I^{\circ}\right.$ s. av. J.-C. $-I I I^{\circ}$ s. ap. J.-C.). Rome 1999, 129-134. 
which young equites crowded the town by exhibiting themselves; in the two funerary reliefs that have been mentioned above, the depiction of the dead as a lupercus is connected to the delivery of the equus publicus. ${ }^{12}$ It has been convincingly argued that this transformation aimed at completing the Romanization of Italy by increasing the importance of the role of the equestrian order in Roman religious and public life. ${ }^{13}$

As a matter of fact, the passage by Suetonius (Aug. 31.4) is the only one testimony of an Augustan restoration of the Lupercalia and available evidence about the festival challenges its reliability. ${ }^{14}$ It is in fact problematic to state that the festival decayed before Augustus. It is well known that Caesar, coherently with his ideological self-representation as new Romulus, ${ }^{15}$ instituted a third team of luperci, the Iulii (Dio Cass. XLIV 6. 2). Moreover, the events occurred during the Lupercalia in 44 BC, when Antonius offered to Caesar the royal crown, ${ }^{16}$ although they are very problematic to interpret, ${ }^{17}$ prove at least that the festival was very popular. According to Cicero (Phil. 13. 31), after Caesar's death the Luperci did not receive the funds that he destined to them (vectigalia Iuliana) any longer, but this does not mean that the celebration vanished.

Furthermore, scholars' assertions, based mainly on Suetonius' passage, are discussable. As regards the dress of the Luperci, it should be retained that, since the statue and the reliefs are portraits, they do not show performing luperci, therefore they can not prove that Augustus dressed them for the festival. Secondly, not only do Virgil and Ovid, two Augustan poets, call the luperci naked, but they insist on luperci's nakedness. For Virgil nakedness is luperci's distinctive symbol, like the dance of Salii and the crest bound with wool for flamines. ${ }^{18}$ Ovid reports three aitiological tales for the nakedness as characteristic ritual feature of Lupercalia: two of them are Greek (related to the Arcadians ${ }^{19}$ and to Faunus ${ }^{20}$ ) and one is Roman (related to the young Romulus and Remus). ${ }^{21}$ Thirdly, it is worth considering that nakedness could be sym-

${ }^{12}$ See VeYNE, P.: Iconographie de la transvectio equitum et des Lupercales. REA 62 (1960) 100-112.

13 See FERRIES, M.-C.: Luperci et Lupercalia de César à Auguste. Latomus 68.2 (2009) 391.

${ }^{14}$ Scholars such as J. A. North and N. McLynn have not any doubt in qualifying Svetonius' passage as an "infamous summary"; see NORTH-MCLYNN (n. 9) 177.

${ }^{15}$ See at least ALFÖLDI, A.: Die Geburt der kaiserlichen Bildsymbolik. Kleine Beiträge zu ihrern Entstehungsgeschichte. MH 8 (1951) 190-215; BURKERT, W.: Caesar und Romulus-Quirinus. Historia 11 (1962) 356-357.

${ }^{16}$ See Cic. Phil. 2. 85-87; 3. 12; 13. 31; Nic. Dam. Vit. Caes. 21. 71-75; Plut. Ant. 12; Caes. 61; Dio Cass. XLIV 11. 2-3.

${ }^{17}$ For some different interpretations, see BIANCHI, U. (Cesare e i lupercali del 44 a.C. StRom 6 (1958) 253-259) who stresses the identification of Caesar with Romulus; M. SORDI (Opposizione e onori: il caso dei Lupercali. In SORDI, M. [a cura di]: Fazioni e congiure nel mondo antico. Milano 1999, 151160), who insists upon the polical aspects; G. DUMÉZIL (La religion romaine archaïque. Paris 1974³, 355) who reads the events as a revival of an ancient coronation ritual; A. FRASCHETTI (Cesare e Antonio ai Lupercalia. In FAles, F. M. - GROTTANELli, C. [eds.]: Soprannaturale e potere nel mondo antico e nelle società tradizionali. Milano 1985, 165-186) who stresses the calendar features of the Lupercalia as frame for the event; J. A. NORTH (Caesar at the Lupercalia. JHR 98 [2008] 114-160) who thinks that the attempt had been planned by Caesar and Antony in advance as a demonstration of Caesar's refusal of the role of rex.

\footnotetext{
${ }^{18}$ See Verg. Aen. 8. 663.

${ }^{19}$ Ov. Fast. 2. 283-302.

${ }^{20}$ According to Ov. Fast. 2. 303-359.

${ }^{21}$ According to Ov. Fast. 2. 358-380 .
} 
bolic, that is, the absence of the Roman citizen's dress, the toga. ${ }^{22}$ Finally, it must not be forgotten that Suetonius did not write that Augustus dressed the naked luperci: he wrote that he forbade beardless youths to join in the runners. It has been correctly argued that such a prohibition had probably nothing to do with decency, but was the indication of the lowest age limit for participation.

As regards women, the picture of their ritual role at the Lupercalia is anything but clear. According to some authors such as Nicholas Damascenus, Plutarch and Valerius Maximus, running luperci hit everybody they met. Plutarch adds that women did not avoid the hits and that they offered their hands to be beaten like schoolgirls. According to Festus and Servius only young women were beaten. According to another gloss by Festus, during the Lupercalia women were purified with the Juno's mantle, that is the goat skin. It is tempting to identify Juno'mantle with the strange hairy hood that is worn by a woman depicted in a gem exhibited at the Kunsthistorisches Museum in Wien. It is in fact possible to suppose that she is participating in the Lupercalia because in the gem there are also a smaller Faunus' head and an object which resembles to the typical whip of luperci. ${ }^{23}$ In addiction there are the late fustigation scenes and the passage by Gelasius I that have been mentioned above. Therefore, it is impossible both to identify any Augustan intervention and to define its aim.

What is more, no evidence suggests that Augustus tamed the bad manners of the luperci. As far as ancient authors describe the festival its features are always the same: luperci run disorderly, they are naked, they hit citizens and matronae; the main ritual instruments are goat skin, blood and milk; the tamed dog is sacrified, the festival symbolically refers to wolves; luperci's route is outside the inaugurated Romulean town; in the myth (and perhaps in the rite) the winner is Remus, who lost the competition to be Rome's founder; the deities of the festival are the semicaper Faunus who lives in the woods and speaks through them (Verg. Aen. 7. 81-95) and a Juno who speaks through the trees of her sacred wood as well (Ov. Fast. 2. 437-440) and who is strongly connected to goats (Festus s.v. Februarius, goat skin as Juno's mantle). It is worth noting that some of these details are provided by authors who live during and after the Augustan age: Virgil describes the oracle of Faunus, Ovid that of Juno; Ovid again reports the mythical victory of Remus; Plutarch describes the rite with goat blood, milk and wool and reports the sacrifice of the dog (Rom. 21. 6-8).

Therefore, it is worth wondering whether it was necessary for Augustus to tame the luperci or their savagery was fully coherent with his ideological programme.

An important element to be considered to answer the question is the date of the Lupercalia, 15th February, that is during the Parentalia, the public celebration of the ancestors which lasted from 13th to 21 st February. In those days ancestors were thought to come back to the town through the mundus: public activities were suspended, no marriages were celebrated, officials put their symbols down. It has been suggested that the luperci themselves represented the returning ancestors because in the Etruscan

\footnotetext{
${ }^{22}$ See Fraschetti, A.: Romolo il fondatore. Roma-Bari 2002, 21-22.

23 See TORTORELla (n. 3) 243.
} 
and Italic tradition wolf is strongly connected with the Underworld. ${ }^{24}$ At least, they represented the world in which parentes lived. All the features of the festival look like an inversion of the ordinary way of life of citizens. But all the foundations myths recall a time in which citizens did not exist yet. Many authors state that the rite came from Arcadia, a primeval land. According to Ovid (Fast. 2. 289-290) the Arcadians who followed Evander "possessed their land before the birth of Jove" and were "older than the moon". ${ }^{25}$ Saint Augustine (Civ. Dei XVIII 12) reports that the route of the Lupercalia was interpreted as a reminder of the salvation from the primeval universal deluge. But most authors set the world of luperci at the origins of the town of Rome by referring their institution or the institution of some of their rituals details to the life of Romulus and Remus before the foundation. Luperci actually dated from "before the dawn of civilization and law" (Cic. Cael. 11.26).

It is well known that Augustus created lots of connections between his person and Romulus: his first consulate started with the same auspicium which appeared to Romulus before he founded Rome ${ }^{26}$ he chose Romulus as neighbour during his lifetime and after. He built his house near the place where Romulus lived, ${ }^{27}$ he restored the Lupercal and, according to A. Carandini, included it in his Palatium together with the Roma quadrata, the Romulean foundation pit. ${ }^{28} \mathrm{He}$ also built his mausoleum in a topographical connection to the Pantheon which stood in or near the place of Romulus-Quirinus' apotheosis. ${ }^{29}$ Finally, Romulus was also the cognomen that he wished to receive or that the Senate proposed him. ${ }^{30}$ Therefore, Augustus' involvement in the

${ }^{24}$ See MASTROCINQUE, A.: Romolo (la fondazione di Roma tra storia e leggenda). Este 1993,
$137-197$.
${ }_{25}$ For translation, see Ovid in Six Volumes. Vol. V: Fasti. With an English Translation by J. G.
FrAZER. Repr. Cambridge, Mass. - London 1976.
${ }^{26}$ See Suet. Aug. 95; App. BC 94.388 . Other authors split the event into different occasions: Dio
Cass. XLVI 46. 2-3; Iul. Obs. 69.
${ }_{27}$ See Dio Cass. LIII 16. 5. For topographical problems, see at least COARELLI, F.: Palatium. Il Palatino dalle origini all'impero. Roma 2012, 129.32. Compare CARAFA, P.: Il Palatino messo a punto. ArchClass 64 (2013) 731-738.

${ }^{28}$ See CARANDINI A. - BRUNO, D.: La casa di Augusto dai "Lupercalia" al Natale. Roma-Bari 2008. Compare the criticism of COARELLI (n. 26) 394-395 and the retort of CARAFA (n. 26) 752-753.

${ }^{29}$ See COARelli, F.: Il Pantheon, l'apoteosi di Augusto e l'apoteosi di Romolo: Città e architettura nella Roma imperiale. Atti del Seminario del 25 ottobre 1981 nel $25^{\circ}$ anniversario dell'Accademia di Danimarca [ARID Suppl. X]. 1983, 40-46; SIMPSON, CH. J.: The Northern Orientation of Agrippa's Pantheon. AC 66 (1997) 173-174; THOMAS, E.: The Architectural History of the Pantheon in Rome from Agrippa to Septimius Severus via Hadrian. Hephaistos 15 (1997) 175-176; HeSBERG, H. V.: Das Mausoleum des Augustus. In StEIN-HÖLKESKAMP, E. - HölKESKAMP, K.-J. (Hrsg.): Erinnerungsorte der Antike. Die römische Welt. München 2006, 349; CARANDINI, A.: Cercando Qurino. Traversata sulle onde elettromagnetiche nel suolo del Quirinale. Torino 2007, 55; LA ROCCA, E.: Dal culto di Ottaviano all'apoteosi di Augusto. In URSO, G. (a cura di): Dicere laudes. Elogio, comunicazione, creazione del consenso. Atti del Convegno Internazionale Cividale del Friuli 23-25 Settembre 2010. Pisa 2010, 185. Compare ZIOLKOWSKI, A. in LTUR IV (1999) 56-57 s.v. Pantheon and ZIOLKOWSKI, A.: Prolegomena to Any Future Metaphysics on Agrippa's Pantheon. In LeONE, A. - PALOMBI, D. - WALKER, S. (a cura di): Res bene gestae. Ricerche di storia urbana su Roma antica in onore di Eva Margareta Steinby. Roma 2007, 465-475.

${ }^{30}$ According to Dio Cass. LIII 16. 6-7 Octavianus wished to be called Romulus, but accepted to be called Augustus because he was aware of the negative nuances of the name Romulus. According to Suet. Aug. 7 some senators proposed the name Romulus. 
(re-)organization of the festival Lupercalia, which was so strongly connected to Romulus, is far from surprising.

The ideological meaning of such a program is quite clear: like Romulus founded the town by separating definitely it from the savagery through the inviolable furrow, Augustus rescued it from the disorder of the civil wars, that, as the Epodos 16 by Horace lively shows, took Rome very closely to the primeval savagery: the dissipation of the rests of Romulus (13-14) is a unique and powerful symbol of the cancellation of his foundation work. Coherently, Augustan poets such as Virgil and Ovid insistently provide impressive representations of the savagery of the primeval time. For example, according to Virgil, Latinus (Aen. 7. 170-181) lives in a palace which inspires awe and fear because of the surrounding woods and of the images of the ancestors. In fact, he is the last and most human king of his dynasty. ${ }^{31}$ His father was Faunus, who was not fully human and who is still present just as a voice among woods. His grandfather was Picus, the woodpecker. It has been suggested that the myth about his transformation into the bird reported both by Virgil (Aen . 7. 187-191) and by Ovid (Met. 14. 320434 ) is a rationalizing tale created to cancel his genuine theriomorphic nature: an odd unique plastic Etruscan vase which depicts an half man and half woodpecker being suggests that stories about hybrid beings could have been told. ${ }^{32}$

The savage origins of the town and of its founder should not be forgotten because they are part of Roman identity. Lupercalia served exactly this purpose: once a year Romans were ritually taken back to the world of their parentes, ancestors, in order to strengthen their civic awareness and pride. The identitary power of the celebration is a good reason to explain its very long duration. Not only had Pope Gelasius I to stop Andromachus' attempt at celebrating the festival in the last years of the fifth century AD, more than a century after Theodosius' interdiction of pagan cults. A festival called Louperkalion was celebrated in Constantinople still in the tenth century AD on the last Carnival day (Const. VII De caer. II 82). It was very different from the Roman one: it was held in the circus, it aimed at honouring God and the emperor at the beginning of springtime, no naked young men ran, even though at the end of the last charriots race, charioteers had to pull their charriot by their own. It would be too much to state that this joke was an heritage of the race of the luperci, but it is enough to see that Lupercalia were a symbol that the new Rome chose as heritage of the old one. Therefore, when Augustus dealt with the Lupercalia, he got possession of a very strong Roman identity symbol that was already fully coherent with his very pondered and balanced ideological programme.

Diana Guarisco

University of Bologna

diana.guarisco@libero.it

${ }^{31}$ See BRELICH, A.: I primi re latini. In BRELICH, A.: Tre variazioni romane sul tema delle origini. Roma $1976^{2}, 57-103$.

${ }^{32}$ See CAPANNA, E.: Vaso a forma di picchio. In CARANDINI-CAPPELli (n. 3) 225. 